\title{
Ectopic Expression of Ralstonia solanacearum Effector Protein PopA Early in Invasion Results in Loss of Virulence
}

\author{
Ayami Kanda, ${ }^{1}$ Masahiko Yasukohchi, ${ }^{1}$ Kouhei Ohnishi, ${ }^{2}$ Akinori Kiba, ${ }^{1}$ Tetsuro Okuno, ${ }^{3}$ \\ and Yasufumi Hikichi' \\ ${ }^{1}$ Laboratory of Plant Pathology and Biotechnology, Kochi University, Nankoku, Kochi, 783-8502, Japan; ${ }^{2}$ Research \\ Institute of Molecular Genetics, Kochi University, Nankoku, Kochi 783-8502, Japan; ' ${ }^{3}$ Laboratory of Plant Pathology, \\ Graduate School of Agriculture, Kyoto University, Kyoto 606-8502, Japan
}

Submitted 30 September 2002. Accepted 17 January 2003.

Ralstonia solanacearum OE1-1 (OE1-1) is pathogenic to tobacco. The type III-secreted effector protein popA of OE1-1 showed $97.6 \%$ identity to $p o p A$ of $R$. solanacearum GMI1000, which is not pathogenic to tobacco. Reverse transcription-polymerase chain reaction analysis showed that pop $A$ in OE1-1 was expressed at $3 \mathrm{~h}$ after inoculation (HAI), but not before, in infiltrated-tobacco leaves. Pathogenicity analysis using a popABC operon-deleted mutant of OE1-1 ( $\triangle \mathrm{ABC})$ showed that pop $A B C$ is not directly involved in the pathogenicity of OE1-1. When Papa, which constitutively expresses $p o p A$, was infiltrated into tobacco leaves, $p o p A$ was expressed by 0.5 HAI. Papa could no longer multiply or spread in tobacco leaves and was no longer virulent. Moreover, the hypersensitive response (HR) and expression of HR-related genes were not induced in Papa-infiltrated leaves. Papa was also avirulent in a tobacco root-dipping inoculation assay. These results suggest that the expression of popA in Papa immediately after invasion triggers the suppression of bacterial proliferation and movement, resulting in loss of virulence. However, Papa retained its virulence when directly inoculated into xylem vessels. This result suggests that tobacco plants can recognize PopA when it is expressed early in disease development, and respond with an effective defense in the intercellular spaces.

Additional keyword: bacterial wilt

Bacterial wilt caused by Ralstonia solanacearum (Yabuuchi et al. 1995) is one of the most devastating bacterial plant diseases in the tropics, subtropics, and warm temperature regions worldwide (Hayward 1991). R. solanacearum GMI1000 (GMI1000), which is nonpathogenic to tobacco plants and pathogenic to tomato plants, elicits a hypersensitive response (HR) when infiltrated into tobacco leaves (Boucher et al. 1985). GMI1000 possesses hrp (hypersensitive response and pathogenicity) genes, which confer the bacterium's ability to elicit the hypersensitive response (HR) in tobacco leaves or to be pathogenic to tomato plants (Boucher et al. 1987; Arlat et al. 1992; Van Gijsegem et al. 1995). Several putative hrp-

Corresponding author: Y. Hikichi; Telephone: +81-88-864-5218; Fax: +81-88-864-5219; E-mail: yhikichi@cc.kochi-u.ac.jp.

The nucleotide and amino acid sequence data of popA, popB, and popC of Ralstonia solanacearum OE1-1 can be found at DDBJ/EMBL/GenBank as accession number AB100882. encoded proteins of this bacterial pathogen share homology with proteins from the animal pathogens of the species Yersinia, Salmonella, and Shigella (Galan and Collmer, 1999). The proteins are assumed to be structural constituents of the type III secretion machinery, which translocates effector proteins out of the cell (Van Gijsegem et al. 1995; Wei et al. 1992; He et al. 1993; Arlat et al. 1994; Gaudriault et al. 1997; Bogdanove et al. 1998; Mudgett and Staskawicz 1998).

In most gram negative plant-pathogenic bacteria, one or two genes in each $h r p$ cluster encode a heat-stable glycine-rich extracellular protein, termed harpin, that can elicit the HR when applied externally to nonhost plant cells (Alfano and Collmer, 1997). The first harpin was isolated from Erwinia amylovora (Wei et al. 1992). In E. amylovora, $\mathrm{HrpN}_{\mathrm{Ea}}$ is important for the elicitation of the HR in tobacco and pathogenicity to apples and pears. In nonpectolytic E. chrysanthemi strains, $\operatorname{HrpN}_{\mathrm{Ech}}$ required for the HR elicitation in tobacco, contributes in a minor way to infectivity on witloof chicory (Bauer et al. 1994, 1995). In Pseudomonas syringae pv. syringae B728A harpin affects virulence on beans only when the bacteria are inoculated onto the surface of leaves (Loniello et al. 1995). However, the general role of harpins in pathogenesis is still uncertain.

In GMI1000, the harpin PopA contains abundant glycine and alanine but no cysteine, and the protein purified from in vitro cultures of GMI1000 can induce an HR-like response in tobacco (Arlat et al. 1994). The induction of PopA accumulation in transgenic tobacco plants, which express popA from GMI1000 under control of the hsr203J promoter, induces the HR and systemic acquired resistance (Belbahri et al. 2001). These pieces of evidence suggest that PopA functions as an elicitor for the HR induction in tobacco plants.

PopA is secreted via the Hrp machinery, and is cotranscribed in an operon with $p o p B$ and $p o p C$. PopB has functional nuclear localization signals, and PopC has leucine-rich repeat (Gueneron et al. 2000; Van Gijgegem et al. 2000). PopB and PopC are also secreted through the Hrp machinery. PopA is involved in the avirulent activity to a Petunia line (Arlat et al. 1994). On the other hand, both a popA mutant and a $p o p A B C$ mutant of GMI1000 retain full virulence on tomato plants and ability to elicit the hypersensitive response in tobacco plants, suggesting that the $p o p A B C$ operon is not required for GMI1000 to provoke disease and induce HR (Arlat et al. 1994; Gueneron et al. 2000). Therefore, there is no evidence that popA alone controls the pathogenicity of the bacteria and the bacterial host range. 
$R$. solanacearum OE1-1 (OE1-1) is pathogenic on tobacco plants (Date et al. 1993; Hikichi et al. 1999). Previous studies on the behavior of OE1-1 in susceptible and resistant cultivars of tomato suggest that vigorous growth of the bacteria in the roots and collars followed by growth in the upper stems are necessary for wilt symptom development (Hikichi et al. 1999; Nakazawa-Nasu et al. 1999). hrp mutants of OE1-1, which lack a functional type III secretion machinery, lose their ability to colonize and multiply in host plants immediately after invasion and cannot induce host responses or provoke disease (Kanda et al. in press). However, no type III effectors involved in the bacterial growth and pathogenicity have yet been reported.

In this paper, we analyze the kinetics of popA expression and its involvement in the proliferation and movement of OE1-1 in tobacco plants. Our results suggest that $R$. solanacearum down-regulates expression of popA early in host invasion. Strains constitutively expressing popA can no longer cause disease unless they are inoculated directly into host xylem vessels.

\section{RESULTS}

\section{popABC operon of OE1-1.}

Based on the nucleotide sequence data of GMI1000, a 5.5-kb DNA fragment containing the pop $A B C$ operon was polymerase chain reaction (PCR)-amplified and the DNA fragment was cloned into pUC118 to create pPop. The nucleotide sequences of popA, popB, and popC were determined from this plasmid.

OE1-1 popA consisted of 1,017 nucleotides, with $97.6 \%$ identity to popA of GMI1000. The putative consensus promoter sequence of HrpB-regulated genes, PIP-box (plant-induciblepromoter, TTCG-N16-TTCG, Salanoubat et al. 2002) was detected upstream of popA at the same position as in GMI1000. PopA of OE1-1 showed high identity (95.0\%) to PopA of GMI1000 in the amino acid sequence but it had deletions of residues 24 to 25, 186 and 193 to 195 compared to PopA of GMI1000.

PopB and PopC of OE1-1 showed high identities (98.2 and $98.9 \%$, respectively) to those of GMI1000 in the deduced amino acid sequences. Bipartite nuclear localization signals and leucine-rich repeat sequences were detected in PopB and PopC of OE1-1, respectively, similarly as those of GMI1000.

\section{Analysis of bacterial gene expression in infiltrated tobacco leaves.}

To obtain the precise kinetics of bacterial gene expression in plants, tobacco leaves infiltrated with bacteria were used for expression analysis of popA and $h r p Y$. Total RNA was extracted from tobacco leaves infiltrated with OE1-1 at 1, 3, and $6 \mathrm{~h}$ after infiltration (HAI) and analyzed by reverse transcription-polymerase chain reaction (RT-PCR).

Expression of popA of OE1-1 was detected at 3 HAI while that of $h r p Y$ was detected at 1 HAI (Fig. 1). A more precise

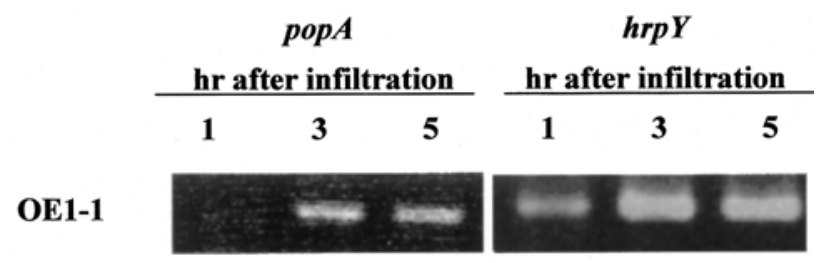

Fig. 1. Reverse transcription-polymerase chain reaction analysis of popA and hrpY of Ralstonia solanacearum strains infecting tobacco leaves. Total RNA was isolated from tobacco leaves infiltrated with $R$. solanacearum $\mathrm{OE} 1-1$ at 1,3 , and $5 \mathrm{~h}$ after inoculation. kinetic analysis of popA expression in OE1-1 infiltrated into tobacco leaves at $0.5,1,2,3$, and $5 \mathrm{HAI}$ showed that popA was not expressed until 3 HAI (Fig. 2B). In tobacco leaves infiltrated with water, no PCR products specific for popA or $h r p Y$ were detected (data not shown).

To analyze the function of $p o p A B C$ in the pathogenicity of OE1-1, the popABC operon, $p o p B$ and $p o p C$, or $p o p C$ of OE11 were replaced with the tetracycline resistance gene using marker exchange to produce strains $\triangle \mathrm{ABC}, \triangle \mathrm{BC}$, and $\triangle \mathrm{C}$, respectively. Analysis using genomic PCR and Southern hybridization confirmed the correct replacement of the popABC operon, $p o p B$ and $p o p C$, or $p o p C$ with the tetracycline resistance gene (data not shown). In peptone yeast (PY) medium and in Boucher's medium, $\triangle \mathrm{ABC}, \triangle \mathrm{BC}$ and $\triangle \mathrm{C}$ grew in a similar manner to OE1-1 (data not shown).

Tobacco plants inoculated with $\triangle \mathrm{ABC}, \triangle \mathrm{BC}$ or $\Delta \mathrm{C}$ by all inoculation methods wilted rapidly in a manner identical to the plants inoculated with wild type strain OE1-1, suggesting that the pop $A B C$ operon is not essential for the pathogenicity (Table 1).

To determine if popBC has an effect on the expression of popA, total RNA was extracted from tobacco leaves infiltrated with $\triangle \mathrm{BC}$ or $\triangle \mathrm{C}$ at $0.5,1,2,3$, and $5 \mathrm{HAI}$ and analyzed by RTPCR. In this popBC background, expression of popA was detected at $3 \mathrm{HAI}$ just as in wild type strain OE1-1 (Fig. 2B), indicating that deletion of $p o p B$ and $p o p C \operatorname{did}$ not influence the expression of $p o p A$ in $\triangle \mathrm{BC}$ and $\triangle \mathrm{C}$.

When PCR amplified, using each RNA sample, from OE1-1 and any transformants-infiltrated tobacco leaves as a template, without cDNA synthesis reaction, any bunds were not observed.

\section{A popA-expressing transformant of $\triangle \mathrm{ABC}$.}

To investigate the effects of constitutive expression of popA and $p o p A B C$ on bacterial virulence, strain $\triangle \mathrm{ABC}$ was transformed with plasmids pPapa and pPABC (Table 2), which contain popA open reading frame (ORF) and ORFs of popABC from OE1-1 fused to a constitutively active promoter from Burkholderia glumae (Hikichi et al. 1999), to create Papa and

(A)

\begin{tabular}{|c|c|c|c|c|c|}
\hline & OF & & & $\mathbf{P a}$ & \\
\hline 1 & 3 & 5 & 1 & 3 & 5 \\
\hline
\end{tabular}

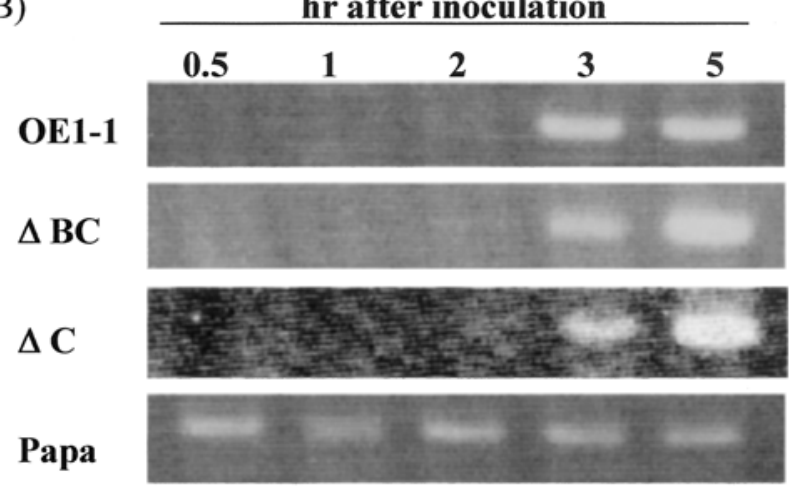

Fig. 2. Reverse transcription-polymerase chain reaction analysis of popA of Ralstonia solanacearum A, OE1-1 and Papa at 0, 1, 3, and $5 \mathrm{~h}$ after incubation in Boucher's medium and $\mathbf{B}, \mathrm{OE} 1-1, \Delta \mathrm{BC}, \Delta \mathrm{C}$, and Papa at $0.5,1,2,3$, and $5 \mathrm{~h}$ after infiltration into tobacco leaves. 
$\mathrm{ABC}$, respectively. Papa and $\mathrm{ABC}$ grew in a similar manner to OE1-1 in potato sucrose (PS) medium (Wakimoto et al. 1968) and in Boucher's medium (data not shown).

Tobacco plants inoculated with OE1-1 by root dipping or stem dipping started to wilt 5 days after inoculation (DAI) and 3 DAI, respectively (Table 1). All the inoculated plants wilted at 10 and 7 DAI, respectively. When OE1-1 was infiltrated into tobacco leaves, the leaves started to wilt at 5 DAI, and then the plants wilted at $10 \mathrm{DAI}$.

Neither Papa nor ABC were virulent when inoculated into tobacco plants using root dipping or when infiltrated into tobacco leaves (Table 1). However, Papa and ABC retained their virulence to tobacco plants when inoculated using the stem dipping method, suggesting that only the transformants inoculated directly into xylem vessels could induce wilting. Because these results indicate that $\mathrm{ABC}$ showed the same pathogenicity to tobacco plants as Papa, only Papa was used in the following studies.

Though OE1-1 and $\triangle \mathrm{ABC}$ showed the same pathogenicity to tomatoes, eggplants, and sweet peppers, Papa, inoculated through the roots, lost its virulence to these Solanum spp. plants but it retained its virulence when inoculated through the cut stems (data not shown).

RT-PCR analysis showed that popA was constitutively expressed in Papa incubated in Boucher's medium (Fig. 2A), and was expressed in tobacco leaves infiltrated with Papa at 0.5 HAI (Fig. 2B). Expression of hrpY of Papa was detected immediately after invasion in a similar manner to that of OE1-1 (data not shown).

The population of wild type strain OE1-1 in infiltrated tobacco leaves increased to $5 \times 10^{8} \mathrm{CFU} / \mathrm{cm}^{2}$ at $5 \mathrm{DAI}$. On the other hand, the population of Papa in the infiltrated region of the tobacco leaves drastically decreased from $3 \times 10^{6} \mathrm{CFU} / \mathrm{cm}^{2}$ at $2 \mathrm{DAI}$ to $5 \times 10^{4} \mathrm{CFU} / \mathrm{cm}^{2}$ until $5 \mathrm{DAI}$, suggesting that the proliferation of $p o p A$-constitutively expressing strain Papa is inhibited in the intercellular spaces (Fig. 3).

In the plate-printing assay (Fig. 4), though OE1-1 and $\triangle \mathrm{ABC}$ were detected at any area at 14 DAI, Papa was never detected beyond the bacteria-infiltrated area, suggesting that Papa lacked the ability to move into the periphery through the intercellular spaces in the infiltrated tobacco.
Expression of plant HR and induced resistance-related genes in tobacco leaves infiltrated with the bacteria.

PopA purified from GMI1000 cultures functions as an HR elicitor (Arlat et al. 1994). The HR-related tobacco genes, $h s r 203 \mathrm{~J}$ and $\mathrm{hin} 1$, are specifically expressed in tobacco leaves inoculated with $R$. solanacearum 8107 (8107), which like GMI1000, induces HR and systemic acquired resistance in infiltrated tobacco leaves and is nonpathogenic to tobacco (Kiba et al. In press). To determine whether these HR-related host genes might play a role in suppression of bacterial growth and movement, accumulation of the mRNAs of $h s r 203 \mathrm{~J}$ and hinl mRNAs in Papa-infiltrated tobacco leaves was analyzed by northern hybridization.

In all bacteria-infiltrated tobacco leaves, weak signals for mRNAs of $h s r 203 J$ were first detected at $3 \mathrm{HAI}$. In tobacco leaves infiltrated with the tobacco nonpathogen 8107, the accumulation reached a maximum at 6 HAI (Fig. 5). On the other hand, hsr203J was only weakly expressed in tobacco leaves infiltrated with tobacco pathogen OE1-1 and constitutive expression of PopA in OE1-1 mutant strain Papa.

In 8107-infiltrated tobacco leaves, mRNAs of hinl were first detected at $3 \mathrm{HAI}$, and mRNA signal intensity reached a maximum at $6 \mathrm{HAI}$. In OE1-1-infiltrated leaves, a weak signal for hinl was first detected at $3 \mathrm{HAI}$. Signal intensity increased gradually, reached a maximum at $9 \mathrm{HAI}$, and then drastically decreased (Fig. 5). On the other hand, in Papa-infiltrated leaves, weak signals for hinl were detected at 3 to $9 \mathrm{HAI}$, and a strong signal was detected at $12 \mathrm{HAI}$ (Fig. 5), suggesting that kinetics of hinl expression in Papa-infiltrated leaves differs from that in OE1-1-infiltrated leaves.

\section{DISCUSSION}

In GMI1000, transcription units 1, 2, 3, and 4 of the hrp gene clusters are induced in the Boucher's medium or in coculture with plant cells through the $h r p B$ regulatory gene (Aldon et al. 2000, Arlat et al. 1992, Genin et al. 1992, Brito et al. 1999, Marenda et al. 1998, Van Gijsegem et al., 1995). The PIP-box has been detected in the upstream regions of each transcript unit in GMI1000 (Salanoubat et al., 2002). The box was also detected in the upstream regions of popA and $h r p Y$ in

Table 1. Virulence of $R$. solanacearum to tobacco plants by different inoculation methods

\begin{tabular}{|c|c|c|c|c|c|c|}
\hline \multirow[b]{2}{*}{ Inoculation methods ${ }^{a}$} & \multirow[b]{2}{*}{ Bacteria } & \multicolumn{5}{|c|}{ Disease Index } \\
\hline & & $2^{b}$ & 4 & 6 & 8 & 10 \\
\hline \multirow[t]{6}{*}{ Root dipping } & OE1-1 & 0 & 0 & 38.4 & 76.3 & 100 \\
\hline & $\triangle \mathrm{ABC}$ & 0 & 0 & 39.1 & 79.4 & 100 \\
\hline & $\triangle \mathrm{BC}$ & 0 & 0 & 36.4 & 82.5 & 100 \\
\hline & $\Delta \mathrm{C}$ & 0 & 0 & 40.5 & 75.2 & 100 \\
\hline & Papa & 0 & 0 & 0 & 0 & 0 \\
\hline & $\mathrm{ABC}$ & 0 & 0 & 0 & 0 & 0 \\
\hline \multirow[t]{6}{*}{ Leaf infiltration } & OE1-1 & 0 & 0 & 19.1 & 52.9 & 100 \\
\hline & $\triangle \mathrm{ABC}$ & 0 & 0 & 20.1 & 59.3 & 100 \\
\hline & $\triangle \mathrm{BC}$ & 0 & 0 & 18.3 & 53.5 & 100 \\
\hline & $\Delta \mathrm{C}$ & 0 & 0 & 25.1 & 60.0 & 100 \\
\hline & Papa & 0 & 0 & 0 & 0 & 100 \\
\hline & $\mathrm{ABC}$ & 0 & 0 & 0 & 0 & 0 \\
\hline \multirow[t]{6}{*}{ Stem dipping } & OE1-1 & 0 & 41.6 & 91.7 & 100 & 0 \\
\hline & $\triangle \mathrm{ABC}$ & 0 & 37.9 & 89.1 & 100 & 100 \\
\hline & $\triangle \mathrm{BC}$ & 0 & 42.9 & 79.8 & 100 & 100 \\
\hline & $\Delta \mathrm{C}$ & 0 & 38.1 & 96.1 & 100 & 100 \\
\hline & Papa & 0 & 43.0 & 95.0 & 100 & 100 \\
\hline & $\mathrm{ABC}$ & 0 & 39.0 & 94.0 & 100 & 100 \\
\hline
\end{tabular}

${ }^{a}$ Eight-week-old tobacco plants were inoculated by dipping the roots of the plants in the bacterial suspension at $10^{8} \mathrm{CFU} / \mathrm{ml}$ for $20 \mathrm{~min}$ (Root dipping), infiltration of the bacterial suspension at $10^{8} \mathrm{CFU} / \mathrm{ml}$ in an approximately $50-\mu \mathrm{l}$ volume into the tobacco leaves using a disposable syringe (Leaf infiltration) or dipping the cut stems in the bacterial suspension at $10^{8} \mathrm{CFU} / \mathrm{ml}$ for 20 min (Stem dipping). Plants were rated daily on a 0 to 4 disease index. Each point represents the mean disease index of 60 plants combined from five separate experiments.

${ }^{b}$ Days after inoculation of the bacteria. 
OE1-1. Moreover, in a $h r p B$-deleted mutant of OE1-1 cultured in the Boucher's medium, popA was not expressed and the mutant lost its parasitic fitness in host plants and its pathogenicity (Kanda et al. In press), suggesting that expression of hrp genes and pop operon in OE1-1 are likely also to be regulated by $\mathrm{HrpB}$ as in GMI1000. However, RT-PCR analysis showed that the timing of the popA expression in OE1-1 infiltrated into tobacco leaves differed from that of $h r p Y$, suggesting that one or more other regulators in addition to $\mathrm{HrpB}$ could control expression of popA in OE1-1.

The induction of $h r p B$ expression is activated by a twocomponent response regulator, $\mathrm{HrpG}$, in response to nutrient conditions and metabolic signals (Brito et al. 1999). Expression of $h r p G$ is sensed by a surface signaling mechanism composed by PrhA-PrhR-PrhI activated after physical bacteriumplant cell contact (Brito et al. 2002). Moreover, accumulated 3$\mathrm{OH}$ palmitic acid methyl ester, which controls expression of the Phc regulon in response to cell density of the bacteria, represses expression of $h r p$ genes (Schell, 2000), and type IIIsecreted proteins of a phcA-mutant of OE1-1 were secreted when incubated in the rich medium (K. Ohnishi, unpublished data). Therefore, expression of $h r p$ regulon may be elaborately regulated since it may be affected not only by each other but also by other factors such as nutrient conditions and metabolic signals.

Gueneron et al (2000) have suggested a possibility that some of the $p o p B$ sequence deleted in a popB mutant of GMI1000 cultured in Boucher's medium might play a role in transcription of popA. The nucleotide sequence of popB of OE1-1 showed high identity (99.2\%) to that of GMI1000, nonetheless RT-PCR analysis showed that deletion of popBC did not affect expression of popA. Moreover, in the Boucher's medium, though expression of $h r p Y$ was detected immediately after incubation in OE1-1 cultured (data not shown), expression of popA was not detected until $3 \mathrm{~h}$ after incubation. Gueneron et al (2000) have also reported that the level of induction of the pop $A B C$ operon is significantly lower in the presence of plant cells than in the Boucher's medium, whereas the level of transcription of hrp units 2, 3, and 4 is similar or slightly higher in the presence of plant cells than in the Boucher's medium. Constitutive expression of popA in Papa was not affected by deletion of $p o p B C$ and did not affect expression of $h r p Y$. Therefore, expression of popA may be regulated by not only HrpB but also nutrient conditions or metabolic signals, which may be transduced in OE1-1 infected into host plants and incubated in Boucher's medium.

Infiltration of OE1-1 induces necrotic lesion of tobacco leaves at $60 \mathrm{HAI}$. The nectrotic lesion differed from necrosis induced at $24 \mathrm{HAI}$ by infiltration of 8107 nonpathogenic to tobacco (Kanda et al. In press). Induction of the necrotic lesion depends on secretion of effectors through hrp secretion machinery, similarly as pathogenicity of the bacteria (Kanda et al. In press). Infiltration of Papa induced the necrotic lesion at 60 HAI (data not shown), and Papa showed virulence when inoculated through cut stem, suggesting that constitutive expression of popA in Papa will not affect delivery of effectors involving in induction of necrotic lesion and virulence. Moreover, RT-PCR analysis showed that pattern of hrpY expression in Papa in vitro and in planta showed similarly as that of OE1-1. These results suggest that constitutive expression of popA in Papa does not affect expression of other hrp genes or prevent delivery of other essential effectors, but is directly involved in loss of virulence of Papa inoculated through the roots and infiltrated into leaves.

RT-PCR analysis of $h r p Y$ pilin gene expression suggests that the type III secretion pilus might be constructed immediately after bacterial invasion and that PopA expressed in Papa during 3 HAI is likely secreted into tobacco cells through the system, in the same way that $P$. syringae pv. glycinea delivers AvrB within a few minutes of contact with plant cells (Huynh et al. 1989). Proliferation of Papa in vitro showed that constitutively expression of popA did not influence bacterial growth. Therefore, PopA protein expressed in Papa immediately after invasion influences the induction of a resistance response as an effector in the infiltrated spaces, and suppresses the bacterial growth and movement in the intercellular spaces, resulting in regulation of the bacterial virulence.

$R$. solanacearum generally invades from wounded roots or natural openings from which secondary roots subsequently emerge, and then proliferates in the intercellular spaces of the inner cortex and vascular parenchyma before invasion into xylem vessels (Hayward, 1991; Seile et al. 1997; Vasse et al. 1995). Pathogenicity analysis of Papa inoculated through the roots showed that a resistance response was induced in the

Table 2. Bacterial strains and plasmids

\begin{tabular}{|c|c|c|}
\hline Designation & Relevant Characteristics & Reference or Source \\
\hline $\begin{array}{l}\text { E. coli } \\
\text { DH5 } \alpha\end{array}$ & F-endAI, relA, $\phi 80$, lacZAM15, hsdR17, supE44, thi-I, recAI, gyrA96 & Hanahan, 1983 \\
\hline \multicolumn{3}{|c|}{ Ralstonia solanacearum } \\
\hline OE1-1 & wild-type, race 1 , biovar 1 , & Date et al. 1993 \\
\hline 8107 & wild-type, race 1 , biovar 1 , & this study \\
\hline$\triangle \mathrm{ABC}$ & OE1-1 $\triangle$ popABC::Tc ${ }^{r}$ & this study \\
\hline$\triangle \mathrm{BC}$ & OE1-1 $\triangle$ popBC::Tc ${ }^{r}$ & this study \\
\hline$\Delta \mathrm{C}$ & OE1-1 $\Delta$ popC::Tc ${ }^{r}$ & this study \\
\hline Papa & A transformant of $\triangle \mathrm{ABC}$ with $\mathrm{pPapa}, \mathrm{Km}^{\mathrm{r}}$ & this study \\
\hline $\mathrm{ABC}$ & A transformant of $\triangle \mathrm{ABC}$ with pPABC, $\mathrm{Km}^{\mathrm{r}}$ & this study \\
\hline \multicolumn{3}{|c|}{ the } \\
\hline pUC118 & $\mathrm{Ap}^{\mathrm{r}}$ & Vieira and Messing, 1987 \\
\hline pMT5056 & $\mathrm{Ap}^{\mathrm{r}}, \mathrm{Tc}^{\mathrm{r}}, \mathrm{pBebd} 2$ derivative & Tsuda et al. 1995 \\
\hline pUCDpro3101 & $\mathrm{Km}^{\mathrm{r}}$, pUCD3101 derivative & Hikichi et al. 1999 \\
\hline pPOP & 5.5-kb fragment containing popABC operon in $\mathrm{pUC} 118, \mathrm{Ap}^{\mathrm{r}}$ & this study \\
\hline pHA & 1.03-kb KpnI and EcoRI fragment containing $h r p A$ in pUC118, $\mathrm{Ap}^{\mathrm{r}}$ & this study \\
\hline $\mathrm{pABC}$ & 1.0-kb KpnI and EcoRI fragment containing $p r h A$ in $\mathrm{pHA}, \mathrm{Ap}^{\mathrm{r}}$ & this study \\
\hline $\mathrm{pBC}$ & 2.09-kb KpnI and EcoRI fragment containing $p o p A$ in $\mathrm{pHA}, \mathrm{Ap}^{\mathrm{r}}$ & this study \\
\hline $\mathrm{pC}$ & 2.66-kb KpnI and EcoRI fragment containing $p o p B$ in $\mathrm{pHA}, \mathrm{Ap}^{\mathrm{r}}$ & this study \\
\hline pABC-tet & pABC with the 1.4-kb tetracycline resistance gene in $K p n I$ site of pABC, $\mathrm{Ap}^{\mathrm{r}}, \mathrm{Tc}^{\mathrm{r}}$ & this study \\
\hline pBC-tet & $\mathrm{pBC}$ with the $1.4-\mathrm{kb}$ tetracycline resistance gene in $K p n \mathrm{I}$ site of $\mathrm{pABC}, \mathrm{Ap}^{\mathrm{r}}, \mathrm{Tc}^{\mathrm{r}}$ & this study \\
\hline pC-tet & $\mathrm{pC}$ with the $1.4-\mathrm{kb}$ tetracycline resistance gene in $K p n I$ site of $\mathrm{pABC}, \mathrm{Ap}^{\mathrm{r}}, \mathrm{Tc}^{\mathrm{r}}$ & this study \\
\hline pPapa & 1.0-kb fragment containing $p o p A$ in pUCDpro3101, $\mathrm{Km}^{\mathrm{r}}$ & this study \\
\hline pPABC & 4.7-kb fragment containing popABC in pUCDpro3101, $\mathrm{Km}^{\mathrm{r}}$ & this study \\
\hline
\end{tabular}


intercellular spaces of the roots similarly as that in the leaves. In addition, virulence in Papa inoculated into the xylem vessels suggests that PopA expressed in the bacteria existing in xylem vessels might not function as an effector for resistance induction or that defense responses induced by early PopA expression are not effective in the xylem.

hsr203J is specifically activated during the early steps of incompatible plant-pathogen interactions and activation of $h s r 203 \mathrm{~J}$ is correlated with programmed cell death occurring in response to diverse pathogens (Pontier et al. 1994, 1998, 1999). hsr203J may be a signaling component or a detoxification effector (Tronchet et al. 2001). Expression of hinl is activated rapidly by harpins from E. amylovora and $P$. syringae. Hin 1 protein is homologous to the NDR1 protein required in the Arabidopsis spp. to mediate disease resistance induction by different $R$ genes specific for the pathogen (Gopalan et al. 1996). These evidences indicate that the expression of these genes is involved in the HR induction. Though PopA possesses HR-elicitor activity when infiltrated into tobacco leaves (Arlat et al. 1994), the induction of necrosis by the HR in tobacco leaves infiltrated with Papa was not observed (data not shown). Moreover, the expression patterns of hsr203J and hinl in Papainfiltrated tobacco leaves suggest that PopA expressed during 3 HAI would not function as a strong elicitor for the HR.

Kinetics of hinl expression in Papa-infiltrated leaves differed from that in OE1-1-infiltrated leaves. In tobacco, salicylic acid (SA) is a critical signaling molecule in the pathway leading to local and systemic disease resistance as well as the expression of acidic types of pathogenesis-related (PR) genes and the hsr203J (Guo et al. 2000, Ohashi and Ohshima 1992, Pontier et al. 1994). In addition, recent studies have demonstrated that jasmonic acid (JA) and ethylene also mediate resistance to certain pathogens, wounding responses, and expression of basic types of PR genes (Memelink et al. 1990, Vijayan et al. 1998, Xu et al. 1994). In 8107-infiltrated leaves, expression of $h s r 203 J$ is regulated by the SA-dependent signaling pathway, whereas the hinl are regulated by the SAindependent pathway (Kiba et al. In press). SA- and JAmediated pathways including gene expression are affected by JA and SA, respectively (Pena-Cortes et al. 1993, Sano et al. 1994, Doares et al. 1995, Niki et al. 1998, Thomma et al. 2000). Therefore, delay of expression of hinl in Papa-infiltrated tobacco leaves might be involved in a change in valance between SA- and JA-mediated pathways, resulting in induction of a resistance response different from the HR to suppress proliferation and movement of Papa in the intercellular spaces.

In the evolution war between plants and pathogens, since the hosts have developed the ability to recognize effectors (Nimchuk et al. 2001), AvrPphF in P. syringae pv. phaseolicola masks the presence of an unknown $a v r$ gene (Tsiamis et al. 2000). Although the selection pressure on the pathogen without any virulence function of the Avr factor will result in selection for loss or mutated versions of the Avr gene, Avr factors with a virulence role will be maintained in the pathogen population (Van der Hoom et al. 2002). Papa lost its virulence not only to tobacco plants but also to other Solanum spp. plants. Since popA is already known to be an avirulence gene to specific Petunia genotypes (Arlat et al. 1994) and might possess unknown virulence functions to other plants, the bacteria might regulate expression of popA but not diminish the expression of popA nor delete popA to infect Solanum spp. plants. Otherwise, its expression might be delayed to allow time for other bacterial factors to be delivered into plant cells. These additional factors might prevent the plants from sensing PopA and other virulence factors.

Genomic analysis reveals that 14 ORFs coding for products related to Avr determinants and 51 candidates for the type III secretion-dependent effectors are distributed on the chromosome and megaplasmid of GMI1000 (Salanoubat et al 2002). Single and multiple frameshifts or insertion sequence insertions occur in putative virulence gene homologues. The emergence of a plant resistance gene that recognizes a virulence gene would abolish the value of the corresponding virulence gene. Salanoubat et al. (2002) have demonstrated that deactivating gene mechanisms may be the result of an evolutionary elimination of genes that have become liabilities for the pathogen. The results in this study suggested that deletion of popABC genes did not affect pathogenicity of OE11. However, expression of popA immediately after invasion resulted in suppression of the bacterial colonization and proliferation. Moreover, expression of popA was suppressed immediately after bacterial invasion into host plants. Taken together, to infect into host plants and cause the disease, $R$. solanacearum not only eliminates and deactivates genes that show a disadvantage for bacterial colonization and proliferation, but also control the expression of genes such as popA.

\section{MATERIALS AND METHODS}

\section{Bacterial strains, plasmids, and culture conditions.}

The bacterial strains and plasmids are listed in Table 2. $R$. solanacearum strains were routinely grown in PS medium (Wakimoto et al. 1968) at $30^{\circ} \mathrm{C}$. Escherichia coli strains were grown in LM medium (Hanahan 1983) at $37^{\circ} \mathrm{C}$. The following antibiotics were used in selective media in the amounts indicated: $50 \mu \mathrm{g}$ of ampicillin per $\mathrm{ml} ;, 50 \mu \mathrm{g}$ of kanamycin per $\mathrm{ml}$; and $50 \mu \mathrm{g}$ of tetracycline per $\mathrm{ml}$. The populations of $R$. solanacearum OE1-1 and Papa in planta were assayed in three independent experiments using Hara-Ono plates (Hara and Ono 1983) and Hara-Ono plates containing kanamycin, respectively.

\section{Plant assays.}

Tobacco plants (Nicotiana tabacum cv. Bright Yellow) were grown in pots containing a mixture of vermiculite/peat moss

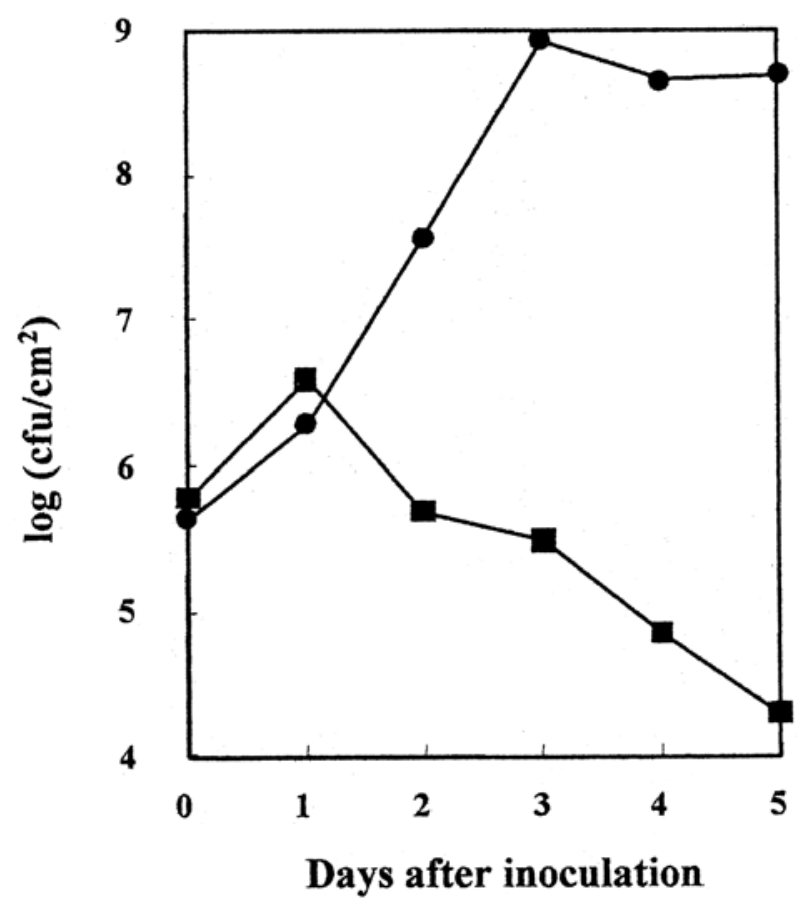

Fig. 3. Population dynamics of Papa and OE1-1 in infiltrated tobacco leaves. The graph shows the average number of bacteria per square centimeter. Closed circles $=$ OE1-1; closed squares $=$ Papa. 


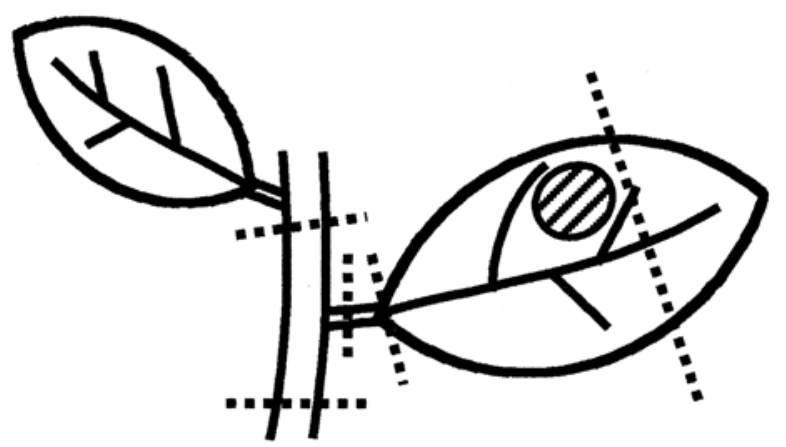

Fig. 4. Cut sites of tobacco plants in plate-printing assay. Tobacco leaves that infiltrated OE1-1, $\triangle \mathrm{ABC}$, or Papa were detached and then cut into three pieces with razor blades at 14 days after infiltration. Stems of the tobacco plants were also cut into three pieces. Dashed lines indicate cut sites. Bacteria were infiltrated into a hatched region.

(3:1) in a growth room at $25^{\circ} \mathrm{C}$ under 10,000 lux for $16 \mathrm{~h}$ per day, and watered with five times-diluted Hoagland's solution (Hikichi et al. 1999). Eight-week-old test plants were inoculated at a bacterial concentration of $10^{8} \mathrm{CFU} / \mathrm{ml}$, and then the plants were grown in water culture pots (Yamato Water Culture Pot No.1, Yamato Plastic Co. Ltd., Tokyo) with five timesdiluted Hoagland's solution in a growth room at $25^{\circ} \mathrm{C}$ under 10,000 lux for $16 \mathrm{~h}$ per day (Hikichi et al. 1999).

\section{Virulence assays.}

The tobacco plants were inoculated with the bacteria using three types of inoculation methods, root-dipping, leaf-infiltration, and stem-dipping. For plant inoculations, the bacteria were resuspended at an optimal density at $600 \mathrm{~nm}\left(\mathrm{OD}_{600}\right)$ of $0.1\left(1.0 \times 10^{8} \mathrm{CFU} / \mathrm{ml}\right)$. For inoculation by root-dipping, the roots of tobacco plants were dipped in the bacterial solution at $10^{8} \mathrm{CFU} / \mathrm{ml}$ for $20 \mathrm{~min}$ and then washed in running water. For infiltration, the bacterial solutions at $10^{8} \mathrm{CFU} / \mathrm{ml}$ in an approximately $50-\mu \mathrm{l}$ volume, measured according to indicators in syringes, were infiltrated into tobacco leaves using a disposable syringe, and for stem-dipping the stems of tobacco plants, with roots and collars removed, were dipped in the bacterial solution at $10^{8} \mathrm{CFU} / \mathrm{ml}$ for $20 \mathrm{~min}$ and then washed in running water. Tobacco plants, inoculated by roots-dipping and stem dipping, were grown, as described in plant assays.

Plants were coded and inspected for wilting symptoms daily for 14 days. Plants were rated on a zero-to-four disease index scale: $0=$ no wilting; $1=1$ to $25 \%$ wilting; $2=26$ to $50 \%$ wilting; $3=51$ to $75 \%$ wilting; and $4=76$ to $100 \%$ wilting or dead. Each assay was repeated in five successive trials. Within each trial, we treated 12 plants with each strain, yielding 60 plants for each strain.

Plate-printing assay was performed as follows (Fig. 4). At 14 DAI with OE1-1, $\triangle \mathrm{ABC}$ and Papa, the bacteria-infiltrated leaves were detached and then cut into three pieces with the razor blades. Stems of the tobacco plants were also cut into three pieces. Cut site of each piece was placed on the HaraOno medium, and the medium was incubated at $30^{\circ} \mathrm{C}$ for 3 days.

\section{Bacterial population in tobacco plants.}

The Papa or OE1-1-infiltrated area $\left(1 \mathrm{~cm}^{2}\right)$ in tobacco leaves was excised from five of each set of plants at 1, 2, 3, 4, and 5 DAI and ground using a mortar and pestle. The original solution and 10-fold serial dilutions of it were dispensed in $0.1 \mathrm{ml}$ of samples and spread onto three plates of the selective agar media of Hara and Ono for OE1-1, or media containing kanamycin at $50 \mu \mathrm{g} / \mathrm{ml}$ for Papa. The numbers of colonies were counted after 2 days of incubation at $30^{\circ} \mathrm{C}$ to estimate the population.

\section{General DNA and RNA manipulations.}

Isolation of genomic DNA, plasmid DNA manipulations, PCR, and Southern blot analyses were performed using standard techniques (Sambrook et al. 1989). R. solanacearum was transformed by electroporation (Allen et al. 1991). Double-stranded DNA sequencing templates were prepared with GenElute Plasmid Miniprep Kits (SIGMA Chemical Co., St. Louis, MO U.S.A.). Sequences were determined using an Automated DNA Sequencer Model 373 (Applied Biosystems, Tokyo). DNA sequence data were analyzed using the DNASISMac software (Hitachi Software Engineering, Yokohama, Japan).

\section{Isolation of the popABC operon.}

A 5.5-kb DNA fragment was PCR-amplified using the following primers based on the nucleotide sequence of GMI1000: 5'-GCTCTAGAGCAACACCGTATCGAGCAGC-3' (named Xba-propopAhrpA) with an added $X b a I$ site (underlined) and 5'-CCCAAGCTTGATCAACGAAGGCGACAGC-3' (named Hind-hrpApopA) with an added HindIII site (underlined), and Ex Taq DNA polymerase (Takara, Ohtsu, Japan). An XbaI and HindIII-digested fragment was ligated into the $X b a \mathrm{I}$ and HindIII sites of pUC118 (Vieira and Messing, 1987) to create pPop.

\section{A pop $A B C$ operon-deleted mutant.}

A 1,030-bp fragment (named HA fragment) was PCR-amplified from the genomic DNA of OE1-1 with the following primers: 5'-GGGGTACCGCATTCGGCAATGAAGAAG C-3' (named Kpn2-1) with an added KpnI site (underlined) and 5'CGGGATCCAATACGTC GGCAACAGCGGC-3' (named Bam1-2) with an added BamHI site (underlined). A KpnI and BamHI-digested HA fragment was ligated into the KpnI and BamHI sites of pUC118 to create pHA. A 1,032-bp fragment (named ABC fragment) was PCR-amplified from the genomic DNA of OE1-1 with 5'-CGGAATTCTACAACGGCG CGACCATGC-3' (named Eco3-1) with an added EcoRI site (underlined) and 5'-GGGGTACCAACCTTTGAGGGCAGG GGGT-3' (named Kpn4) with an added KpnI site (underlined). A 2,092-bp fragment (named BC fragment) was PCRamplified from the genomic DNA of OE1-1 with Eco3-1 and 5'-GGGGTACCGAAAGCGGACAGCCGTTGCC-3' (named Kpn8-1) with an added KpnI site (underlined). A 2,656-bp fragment (named $\mathrm{C}$ fragment) was PCR-amplified from the genomic DNA of OE1-1 with Eco3-1 and 5'-GGGGTACC ACGATCAGTCGTCGTCGTCC-3' (named Kpn6-1) with an added KpnI site (underlined). The ABC fragment, BC fragment, and $\mathrm{C}$ fragment were digested with $K p n \mathrm{I}$ and EcoRI, and the fragments were ligated into the $K p n \mathrm{I}$ and EcoRI sites of pHA to create $\mathrm{pABC}, \mathrm{pBC}$, and $\mathrm{pC}$, respectively. The KpnIdigested fragment containing the tetracycline-resistance gene from pMT5056 (Tsuda et al. 1995) was ligated into the KpnI sites of $\mathrm{pABC}, \mathrm{pBC}$, and $\mathrm{pC}$ to create $\mathrm{pABC}$-tet, $\mathrm{pBC}$-tet, and pC-tet, respectively. $\triangle \mathrm{ABC}, \triangle \mathrm{BC}$, and $\triangle \mathrm{C}$ were created using the pABC-tet, pBC-tet, and $\mathrm{pC}$-tet, respectively, by the markerexchange. Each plasmid was electroporated into OE1-1 and then tetracycline-resistant tranformants were isolated. PCRamplification using genomic DNA of the transformants as templates and pop3 (5'-TCGAAGACGGCCAGATCACC-3') and pop5 (5'-TGTTCTGGCGCAGCAAGCAG-3') as primers was performed. When used genomic DNA of OE1-1 as a template, a 5.6-kb DNA fragment was detected. Transformants with pABC-tet, pBC-tet, and pC-tet in which 2.3-, 3.3-, and $3.8-\mathrm{kb}$ DNA fragments were detected, respectively, were 

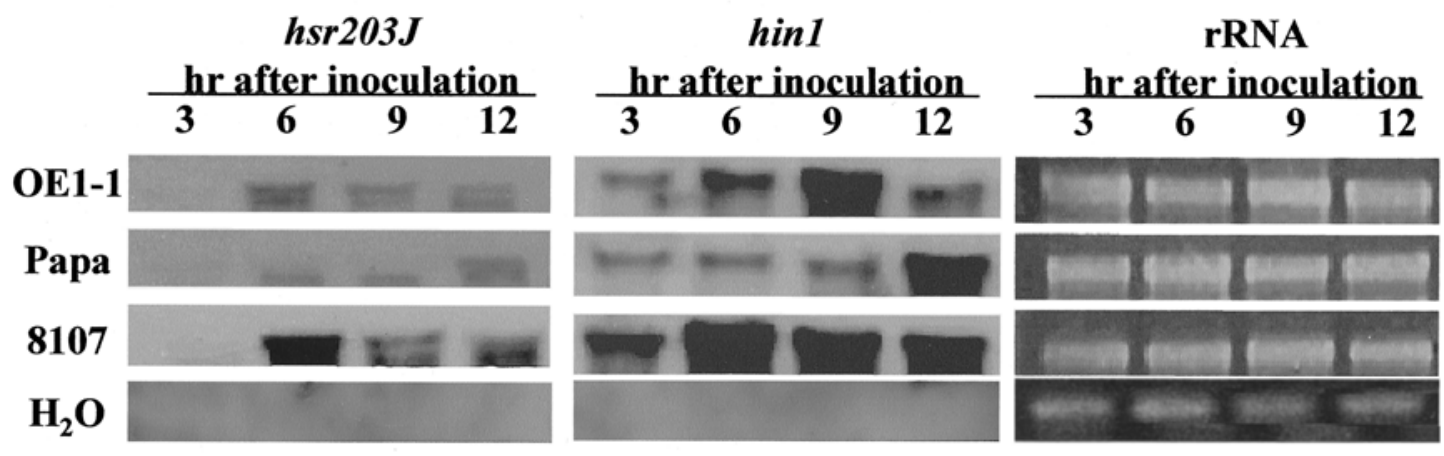

Fig. 5. Northern blot hybridization analysis of $h s r 203 \mathrm{~J}$ and hinl in tobacco leaves infiltrated with Ralstonia solanacearum strains.

selected. DNA sequences of these fragments were analyzed using pop3 and pop5 as primers, as described above and $\triangle \mathrm{ABC}, \triangle \mathrm{BC}$ and $\triangle \mathrm{C}$ were selected.

\section{Construction of pPapa and pPABC.}

A 1.0-kb DNA fragment containing a popA ORF was PCRamplified from OE1-1 with the following primers: 5'-GGA AGATCTATGTCAGTCGGAAACATC-3' (named popA-Bgl) with an added $B g l$ II site (underlined) and 5'-GCC AAGCTTACATCGGCTGCGTCGAGG-3' (named popAHind) with an added HindIII site (underlined). The BglII and HindIII-digested DNA fragment was ligated into the BamHI and HindIII sites of pUCD3101pro containing the constitutively active promoter from Burkholeria glumae (Hikichi et al. 1999) to create pPapa.

A 4.7-kb DNA fragment containing ORFs of the popABC operon was PCR-amplified from OE1-1 with popA-Bgl and 5'GCTCTAGATCAACGCTGCCTCGACGGACT-3' (named xba-popC) with an added $X b a I$ site (underlined). The $B g l \mathrm{II}$ and $X b a \mathrm{I}$-digested DNA fragment was ligated into the Bam $\mathrm{HI}$ and $X b a \mathrm{I}$ sites of pUCD3101pro to create pPABC.

pPapa and pPABC were electroporated into $\triangle \mathrm{ABC}$ to create Papa and $\mathrm{ABC}$, respectively.

\section{RT-PCR of popA and hrpY.}

The bacteria-infiltrated area in tobacco leaves $(0.6 \mathrm{~g})$ was homogenized in RNA extraction buffer $(100 \mathrm{mM}$ glycine $\mathrm{pH}$ 9.5, $10 \mathrm{mM}$ EDTA, $0.1 \mathrm{M} \mathrm{NaCl}, 1 \%$ [wt/vol] sodium dodecyl sulfate (SDS), $0.1 \%$ [wt/vol] bentonite), extracted with phenol/chloroform/isoamyl alcohol (25:24:1) twice, and then extracted with chloroform/isoamyl alcohol (24:1). The aqueous phase was mixed with one-third volume of $10 \mathrm{M} \mathrm{LiCl}$ and incubated at $-20^{\circ} \mathrm{C}$ for $2 \mathrm{~h}$. After centrifugation at $17,500 \times g$ for $30 \mathrm{~min}$, the pellet was washed with $2 \mathrm{M}$ lithium solution (2 $\mathrm{M} \mathrm{LiCl}, 50 \mathrm{mM}$ EDTA), and then the pellet was dissolved in Tris-EDTA (TE) buffer. Phenol extraction and ethanol precipitation were performed to recover the RNA. DNase I (Ambion, Texas, U.S.A) was treated to remove the genomic DNA containing RNA preparation prior to RT-PCR.

The bacteria at $\mathrm{OD}_{600}$ of 0.8 were incubated in Boucher's medium (Boucher et al. 1985) at $30^{\circ} \mathrm{C}$ for appropriate time, and RNA was extracted with High Pure RNA Isolation Kit (Roche Diagnostics, Mannheim, Germany) according to the manufacturer's protocols.

cDNA fragments of popA and $h r p Y$ were synthesized from total RNA $(6 \mu \mathrm{g})$ using Reverse Transcriptase RAV-2 (Vieira and Messing, 1987) with the primers 5'-GTTGGCACCG TTGACATCG C-3' (named SQ-) and 5'-CGGGGATCCTT AGCTGATCAGGTCCTTGGC-3' (named hrpY-Bam), respectively. PCR was then carried out using 5'-CTGGGTG AAGCTGCTGAAGGC-3' (named SQ+) and SQ- for the amplification of a 320-bp DNA fragment specific to popA, and 5'-GGAATTCCATATGGCAGGCGTTCCGAAC-3' (named Nde-hrpY) and hrpY-Bam for the amplification of a 250-bp DNA fragment specific to $h r p Y$.

\section{Northern analysis of $h s r 203 J$ and $h i n 1$.}

Total RNA $(10 \mu \mathrm{g})$ was separated in a $1.5 \%$ agarose gel under denaturing conditions and blotted onto Hybond $\mathrm{N}+$ membrane (Amersham Pharmacia Biotech, Buckinghamshire, U.K.) and then cross-linked to the blots by UV illumination at $1200 \times$ $100 \mu \mathrm{J} / \mathrm{cm}^{2}$ using a Funa-UV-Crosslinker (Funakoshi, Tokyo). The membranes were prehybridized for at least $1 \mathrm{~h}$ in UltraHyb (Ambion, Austin, TX U.S.A.) at $68^{\circ} \mathrm{C}$. The membranes were hybridized at $68^{\circ} \mathrm{C}$ for $16 \mathrm{~h}$ with DIG-labeled RNA probes (Roche Molecular Biochemicals, Indianapolis, IN U.S.A.) of hinl-SNN (Kiba et al. in press) and hsr203J-BY (Kiba et al. in press) according to the manufacturer's manual. After washing in $2 \times \mathrm{SSPE}$ with $0.1 \% \mathrm{SDS}$ at $68^{\circ} \mathrm{C}$ and $0.1 \times$ SSPE with $0.1 \%$ SDS at $68^{\circ} \mathrm{C}$, the membranes were immersed in a blocking solution (Roche Molecular Biochemicals) for 60 min and then incubated with anti-digoxigenin-AP Fab fragments ( $10^{4}$ dilution). Ig-bound RNA was visualized with CDPStar according to the manufacturer's protocols (Roche Molecular Biochemicals). Chemifluorescence was detected by exposing the membrane to X-ray film for 5 to $30 \mathrm{~min}$.

\section{ACKNOWLEDGMENTS}

We would like to thank Dr. C. Allen for critical reading of the manuscript. This work was supported by Grants-in Aid for Scientific Research on priority area (A) from the Ministry of Education, Science, Sports and Culture of Japan.

\section{LITERATURE CITED}

Aldon, D., Brito, B., Boucher, C., and Genin, S. 2000. A bacterial sensor of plant cell contact controls the transcriptional induction of Ralstonia solanacearum pathogenicity genes. EMBO (Eur. Mol. Biol. Organ.) J. 19:2304-2314.

Alfano, J. R., and Collmer, A. 1997. The type III (Hrp) secretion pathway of plant pathogenic bacteria; Trafficking harpins, avr proteins, and death. J. Bacteriol. 179:5655-5662.

Allen, C., Huang, Y., and Sequeira, L. 1991. Cloning of genes affecting polygalacturonase production in Pseudomonas solanacearum. Mol. Plant-Microbe Interact. 4:147-154.

Arlat, M., Gough, C. L., Zischek, C., Barberis, P., Trigalet, A., and Boucher, C.A. 1992. Transcriptional organization and expression of the large hrp gene cluster of Pseudomonas solanacearum. Mol. PlantMicrobe Interact. 5:187-193.

Arlat, M., Van Gijsegum, F., Huet, J. C., Pernollet, J. C., and Boucher, C. A. 1994. PopA1, a protein which induces a hypersensitive-like response on specific Petunia genotypes, is secreted via the Hrp pathway of Pseudomonas solanacearum. EMBO (Eur. Mol. Biol. Organ.) J. 13:543-553.

Bauer, D. W, Bogdanove, A. J., Beer, S. V, and Collmer, A. 1994. Erwinia 
chrysanthemi hrp genes and their involvement in soft rot pathogenesis and elicitation of the hypersensitive response. Mol. Plant Microbe Interact. 7:573-81.

Bauer, D. W, Wei, Z. M, Beer, S. V., and Collmer, A. 1995. Erwinia chrysanthemi harpin $\mathrm{Ech}_{\mathrm{Ec}}$ : An elicitor of the hypersensitive response that contributes to soft-rot pathogenesis. Mol Plant Microbe Interact 8:484491

Belbahri, L., Boucher, C., Candresse, T., Nicole, M., Ricci, P., and Keller, H. 2001. A local accumulation of the Ralstonia solanacearum PopA protein in transgenic tobacco renders a compatible plant-pathogen interaction incompatible. Plant J. 28:419-30.

Bogdanove, A. V., Bauer, D. W., and Beer, S. V. 1998. Erwinia amylovora secretes DspE, a pathogenicity factor and functional AvrE homolog, through the Hrp (type III secretion) pathway. J. Bacteriol. 180:2244-2247.

Boucher, C. A., Barberis, P. A., Trigaret, P. A., and Demery, D. A. 1985. Transposon mutagenesis of Pseudomonas solanacearum: isolation of Tn5-induced avirulent mutants. J. Gen. Microbiol. 131:2449-2457.

Boucher, C. A., Van Gijsegem, F., Barberis, P., Arlat, M., and Zischek, C. 1987. Pseudomonas solanacearum genes controlling both pathogenicity on tomato and hypersensitive on tobacco are clustered. J. Bacteriol. 169: 5626-5632.

Brito, B., Aldon, D., Barberis, P., Boucher, C., and Genin, S. 2002. A signal transfer system through three compartments tranduces the plant cell contact-dependent signal controlling Ralstonia solanacearum hrp genes. Mol. Plant-Microbe Interact. 15:109-119.

Brito, B., Marenda, M., Barberis, P., Boucher, C., and Genin, S. 1999. prhJ and $h r p G$, two new components of the plant signal-dependent regulatory cascade controlled by PrhA in Ralstonia solanacearum. Mol. Microbiol. 31:237-251.

Date, H., Nasu, H., and Hatamoto M. 1993. Thermal death range of Pseudomonas solanacearum under various conditions. Ann. Phytopathol. Soc. Jpn. 59:709-713.

Doares, S. H., Narvaez-Vasquez, J., Conconi, A., and Ryan C. A. 1995 Salicylic acid inhibits synthesis of proteinase inhibitors in tomato leaves induced by systemin and jasmonic acid. Plant Physiol. 108:1741-1746

Galan, J. E., and Collmer, A. 1999. Type III secretion machines: Bacterial devices for protein delivery into host cells. Science 284:1322-1328.

Gaudriault, S., Malandrin, L., Paulin, J. P., and Barny, M. A. 1997. DspA, an essential pathogenicity factor of Erwinia amylovora showing homology with AvrE of Pseudomonas syringae, is secreted via the Hrp secretion pathway in a Dsp-B dependent way. Mol. Microbiol. 26:1057-1069.

Genin, S., Gough, C. L., Zischek, C., and Boucher, C. A. 1992. Evidence that the $h r p B$ gene encodes a positive regulator of pathogenicity genes from Pseudomonas solanacearum. Mol. Microbiol. 6:3065-3076.

Gopalan, S., Wei, W., and He, S. Y. 1996. Hrp gene induction of HIN1, a plant gene activated rapidly by both harpins and the avrPto genemediated signal. Plant J. 10:591-600

Gueneron, M., Timmers, A. C., Boucher, C., and Arlat, M. 2000. Two novel proteins, PopB, which has functional nuclear localization signals, and PopC, which has a large leucine-rich repeat domain, are secreted through the Hrp-secretion apparatus of Ralstonia solanacearum. Mol. Microbiol. 36:261-277.

Guo, A., Salih G., and Klessig, D. F. 2000. Activation of a diverse set of genes during the tobacco resistance response to TMV is independent of salicylic acid; Induction of a subset is also ethylene independent. Plant J. 21:409-418.

Hanahan, D. 1983. Studies on transformation of Escherichia coli with plasmids. J. Mol. Biol. 166:557-580.

Hara, H., and Ono, K. 1983. Ecological studies on the bacterial wilt of tobacco, caused by Pseudomonas solanacearum E. F. Smith. I. A selective medium for isolation and detection of $P$. solanacearum. Bull. Okayama Tob. Exp. Stn. 42:127-138.

Hayward, H. C. 1991. Biology and epidemiology of bacterial wilt caused by Pseudomonas solanacearum. Annu. Rev. Phytopathol. 29:65-87.

He, S. Y., Huang, H. C. and Collmer, A. 1993. Pseudomonas syringae pv. syringae harpin ${ }_{\mathrm{Pss}}$ : A protein that is secreted via the Hrp pathway and elicits the hypersensitive response in plants. Cell 73:1255-1266.

Hikichi, Y., Nakazawa-Nasu, Y., Kitanosono, S., Suzuki, K., and Okuno, T. 1999. The behavior of genetically lux-marked Ralstonia solanacearum in grafted tomato cultivars resistant or susceptible to bacterial wilt. Ann. Phytopathol. Soc. Jpn. 65:597-603.

Huynh, T. V., Dahlbeck, D., and Staskawicz, B. J. 1989. Bacterial blight of soybean: Regulation of a pathogen gene determining host cultivar specificity. Science 245:1374-1377.

Kanda, A., Ohnishi, S., Tomiyama, H., Hasegawa, H., Yasukohchi, M., Kiba, A., Ohnishi, K., Okuno, T., and Hikichi, Y. Type III-secretion machinery deficient mutants of Ralstonia solnacearum lose their abil- ity to colonize, proliferate and induce host responses immediately after invasion, resulting in loss of their virulence. J. Gen. Plant Pathol. In press.

Kiba, A., Tomiyama, A., Takahashi, H., Hamada, H., Ohnishi, K., Okuno, K., and Hikichi, Y. Induction of resistance and expression of defenserelated genes in tobacco leaves infiltrated with Ralstonia solanacearum. Plant Cell Physiol. In press.

Loniello, A. O., Alfano, J. R., Bauer, D.W., and Collmer, A. 1995. Analysis of pathogenicity of a Pseudomonas syringae pv. syringae B728a AhrpZ::nptII mutant on bean. (abstr.) Phytopathology 85:1148.

Marenda, M., Brito, B., Callard, D., Genin, S., Barberis, P., Boucher, C., and Arlat, M. 1998. PrhA controls a novel regulatory pathway required for the specific induction of Ralstonia solanacearum hrp genes in the presence of plant cells. Mol. Microbiol. 27:437-453.

Memelink, J., Linthorst, H. J. M., Schilperoort, R. A. and Hoge, J. H. 1990. Tobacco genes encoding acidic and basic isoforms of pathogenesis-related proteins display different expression patterns. Plant Mol. Biol. 14:119-126.

Mudgett, M. B. and Staskawicz, B. J. 1998. Protein signaling via type III secretion pathway in phytopathogenic bacteria. Curr. Opin. Microbiol. $1: 109-114$

Nakazawa-Nasu, Y., Kitanosono, S., Hasegawa, H., Okunoya, K., Yaegaki, F., Suzuki, K., Hikichi, Y., and Okuno, T. 1999. Detection of Ralstonia solanacearum using tissue printing immunoassay. Ann. Phytopathol. Soc. Jpn. 65:549-552.

Niki, T., Mitsuhara, I., Seo, S., Ohtsubo, N., and Ohashi, Y. 1998. Antagonistic effect of salicylic acid and jasmonic acid on the expression of pathogenesis-related (PR) protein genes in wounded mature tobacco leaves. Plant Cell Physiol. 39:500-507.

Nimchuk, Z., Rohmer, L., Chang, J. H., and Dangl, J. L. 2001. Knowing the dancer from the dance: R-gene products and their interactions with other proteins from host and pathogen. Curr. Opinion Plant Biol. 4:288-294.

Ohashi, Y., and Ohshima, M. 1992. Stress-induced expression of gene for pathogenesis-related proteins in plants. Plant Cell Physiol. 33:819826.

Pena-Cortes, H., Albrecht, T., Prat, S., Weiler, E.W., and Willmitzer, L. 1993. Aspirin prevents wounding-induced gene expression in tomato leaves by blocking jasmonic acid biosynthesis. Planta 191:123-128.

Pontier, D., Gan, S., Richard, M. A., Robby, D. and Lam, E. 1999. Markers for hypersensitive response and senescence show distinct patterns of expression. Plant Mol. Biol. 39:1243-1255.

Pontier, D., Godiard, L., Marco, Y., and Roby, D. 1994. HSR203J, A tobacco gene whose activation is rapid, highly localized and specific for incompatible plant-pathogen interactions. Plant J. 5:507-521.

Pontier, D., Tronchet, M., Rogowsky, P., Lam, E., and Roby, D. 1998. Activation of $h s r 203$, a plant gene expressed during incompatible plant-pathogen interactions, is correlated with programmed cell death. Mol. Plant-Microbe Interact. 11:544-554.

Salanoubat, M., Genin, S., Artiguenave, F., Gouzy, J., Mangenot, S., Arlat, M., Billault, A., Brottier, P., Camus, J. C., Cattolico, L., Chandler, M., Choisne, N., Claudel-Renard, C., Cunnac, S., Demange, N., Gaspin, C., Lavie, M., Moisan, A., Robert, C., Saurin, W., Schiex, T., Siguier, P., Thebault, P., Whalen, M., Wincker, P., Levy, M. Weissenbach, J., and Boucher, C. A. 2002. Genome sequence of the plant pathogen Ralstonia solanacearum. Nature 415:497-502.

Sambrook, J., Fritsch, E. F., and Maniatis, T. 1989. Molecular cloning: a laboratory manual, 2nd ed. Cold Spring Harbor Laboratory Press, Cold Spring Habor, NY.

Sano, H., Seo, S., Orudgev, E., Youssefian, S., Ishizuka, K., and Ohashi, Y. 1994. Expression of the gene for a small GTP binding protein in transgenic tobacco elevates endogeneous cytokinin levels, abnormally induces salicylic acid in response to wounding, and increases resistance to tobacco mosaic virus infection. Proc. Natl. Acad. Sci. U.S.A. 91:10556-10560

Schell, M. A. 2000. Control of virulence and pathogenicity genes of Ralstonia solanacearum by an elaborate sensory array. Annu. Rev. Phytopathol. 38:263-292.

Seile, E., McGarvey, J. A., Schell, M. A., and Denny, T. P. 1997. Role of extracellular polysaccharide and endoglucanase in root invasion and colonization of tomato plants by Ralstonia solanacearum. Phytopathology 87:1264-1271.

Thomma, B. P. H. J., Penninckx, I. A. M. A., Broekart, W. F., and Cammue, B. P. A. 2000. The complexity of disease signaling in Arabidopsis. Curr. Opin. Immunol. 13:63-68.

Tronchet, M., Ranty, B., Marco, Y., and Roby, D. 2001. HSR203 antisense suppression in tobacco accelerates development of hypersensitive cell death. Plant J. 27:115-127.

Tsiamis, G, Mansfield, J. W, Hockenhull, R, Jackson, R. W., Sesma, A. 
Athanassopoulos, E., Bennett, M. A., Stevens, C., Vivian, A., Taylor, J. D., and Murillo, J. 2000. Cultivar-specific avirulence and virulence functions assigned to avrPphF in Pseudomonas syringae pv. phaseolicola, the cause of bean halo-blight disease. EMBO (Eur. Mol. Biol. Organ.) J. 19:3204-3214.

Tsuda, M., Miyazaki, H., and Nakazawa, T. 1995. Genetic and physical mapping of genes involved in pyoverdin production in Pseudomonas aeruginosa PAO. J. Bacteriol. 177:423-431.

Van der Hoom, R. A. L., De Wit, P. J. G. M., and Joosten, M. H. A. J. 2002. Balancing selection favors guarding resistance protein. Trends Plant Sci. 7:67-71.

Van Gijsegem, F., Gough, C., Zischek, C., Niqueux, E., Arlat, M, Genin, S., Barberis, P., German, S., Castello, P., and Boucher, C. 1995. The hrp gene cluster of Pseudomonas solanacearum, which controls the production of a type III secretion system, encodes eight proteins related to components of the bacterial flagellar biogenesis complex. Mol. Microbiol. 15:1095-1114

Van Gijsegem, F., Vasse, J., Camus, J.-C., Marenda, M., and Boucher, C. 2000. Ralstonia solanacearum produces Hrp-dependent pili that are required for PopA secretion but not for attachment of bacteria to plant cells. Mol. Microbiol. 36:249-260.

Vasse, J., Frey, P., and Trigalet, A. 1995. Microscopic studies of intercellular infection and protoxylem invasion of tomato roots by
Pseudomonas solanacearum. Mol. Plant-Microbe Interact. 8:241-251.

Vieira, J., and Messing, J. 1987. Production of single-stranded plasmid DNA. Methods Enzymol. 153:3-11.

Vijayan, P., Shockey, J., Levesque, C. A., Cook, R. J., and Browse, J. 1998. A role for jasmonate in pathogen defense of Arabidopsis. Proc. Natl. Acad. Sci. U.S.A. 95:7209-7214.

Wakimoto, S., Uematsu, T., and Mukoo, H. 1968. Bacterial canker disease of tomato in Japan. 1. Isolation and identification of the causal bacteria, and resistance of tomato varieties against the disease. Bull. Natl. Inst. Agric. Sci. Ser. C. 22:269-279.

Wei, Z. M., Laby, R. J., Zumoff, C. H., Bauer, D. W., He, S. Y., Collmer A., and Beer, S. V. 1992. Harpin, elicitor of the hypersensitive response produced by the plant pathogen Erwinia amylovora. Science 257:85-88.

Xu, Y., Chang, P-F. L., Liu, D., Narasimhan, M. L., Raghothama, K. G., Hasegawa, P. M., and Bressan, R. A. 1994. Plant defense genes are synergistically induced by ethylene and methyl jasmonate. Plant Cell 6:1077-1085

Yabuuchi, E., Kosako, Y., Yano, I., Hotta, H. and Nishiuchi, Y. 1995. Transfer of two Burkholderia and an Alcaligenes species to Ralstonia gen.: Proposal of Ralstonia pickettii (Ralston, Palleroni and Doudoroff, 1973) comb. Nov., Ralstonia eutropha (Davis, 1962) comb. nov. Microbiol. Immunol. 39:897-904 